\begin{tabular}{c} 
Volume and Issues Obtainable at Center for Sustainability Research and Consultancy \\
Journal of Business and Social Review in Emerging Economies \\
ISSN: 2519-089X \& ISSN (E): 2519-0326 \\
Volume 7: Issue 2 June 2021 \\
JSR \\
Journal homepage: www.publishing.globalcsrc.org/jbsee \\
\hline
\end{tabular}

\title{
Role of Prayers in Anxiety Management among the Youth of Pakistan: An Exploratory Study
}

*Ghulam Shabir, Professor Faculty of Media and Communication Studies, University of Central Punjab, Lahore, Pakistan

Arif Ahmad, Visiting lecturer at National University of Modern languages, Pakistan, Postgraduate from Faculty of Media and Communication studies University of Central Punjab Lahore, Pakistan

Imran Shah, Phd scholar Department of Media Studies Islamia University Bahawalpur, Pakistan

Faizan Ali, Assistant Professor, HOD, Beaconhouse National University Lahore, Pakistan

*Corresponding author's email address: ghulam.shabir@ucp.edu.pk

\begin{tabular}{lll}
\hline RTICLE DETAILS & & ABSTRACT \\
${ } }$ & Background: Regular feelings of anxiety is a severe life and highly
\end{tabular}

Revised format: Feb 2021

Available Online: Mar 2021 prevalent psychiatric disorder which becomes one of the major cause of death across the globe. Although the exact causes responsible for

\section{Keywords}

Anxiety, Prayers, youth, Tension, God,

\section{JEL Classification}

M10, M14 anxiety are not known only in Pakistan $44 \%$ of the population is facing anxiety problems which leads to many other diseases and low quality of life. Objectives: To investigate whether the youth of Pakistan is facing anxiety problems, what are the major cause of anxiety, how anxiety can be managed, and to study the role of prayers in anxiety management. Method: The researcher select 400 respondents from two universities of Lahore (the University of Central Punjab and Punjab University) through a systematic random sampling technique. In the first phase, the researcher filters those people who did not face an anxiety problem in the last month. Researchers collect data only from those respondents who can recall and face an anxiety problem in the last month. Results: Rate of anxiety among the youth of Pakistan is alarming, as (71\%) of the respondent said that they face anxiety problems. But there is a very significant relationship between prayers and anxiety management. Conclusion: The researcher concludes that prayers can be used to manage or reduce anxiety.

(C) 2021 The authors, under a Creative Commons AttributionNonCommercial 4.0

Recommended citation: Shabir, G., Ahmad, A., Shah, I. \& Ali, R.F. (2021). Role of Prayers in Anxiety Management among the Youth of Pakistan: An Exploratory Study. Journal of Business and Social Review in Emerging Economies, 7(1), 15-22

\section{Introduction}

More than 300 million people are facing anxiety problems all over the world and this number increased by $18 \%$ between 2005 and 2015(Malik \& Björkqvist, 2018). Likewise in Pakistan, 44\% of the entire population is affected by depression and anxiety. Its prevalence is high in women $57 \%$ and $25 \%$ in men (Arif, Naveed, \& Aslam, 2017). Anxiety, stress, or tension is most often negative and harmful thoughts. It can cause serious problems if its intensity is high and it lasts for a long time. It is a serious problem 
facing younger and older age people who need attention because too much stress can lead to serious health risks. Prayer is one of the best remedies which can be used to reduce anxiety (Kay \& Tasman, 2006). Prayer means communication with the creator (Levin, 1996). It is a religious activity practiced all over the world (Levin \& Taylor, 1997). Prayer is the religious activity through which one makes a spiritual hotline to the supreme force in the universe. More than $90 \%$ of people prayed once a day. Frequency of prayers increases with the older age (Smolensky, 1998). There is a strong connection between faiths and healing, prayers can be used to reduce stress and anxiety and increase the healing rate (Harris, 2008). Prayer is considered an alternative to medicine that produces healing. It can be used along with other traditional medical procedures.

It is also found that in some cases the prayers can replace all other methods to reduce depression, tension, and anxiety. Greater trust in prayers and frequency of prayers in one's life can reduce the anxiety in his life (Stephenson, Weinrich, \& Tavakolil, 2000). Prayers are positively associated with mental health (Jim et al., 2015). The studies stated that beliefs and prayers are directly associated with improved physical and mental health. Prayers increase higher levels of satisfaction with life, hope, a lower rate of anxiety and depression (Panzini \& Bandeira, 2007). As prayers increase hope and reduce negative thoughts so it leads to reduce stress and improve quality of life (Simão, Caldeira, \& de Carvalho, 2016). Prayer provides comfort in times of distress, as religion is associated with robust mental health (Moreira-Almeida, Lotufo Neto, \& Koenig, 2006).

There are many studies available on the causes of depression, anxiety, and stress Management. Although there is little literature available, for controlling the problem. The implication of this study will help us to understand the role of prayers to manage stress and anxiety. The finding can reveal discourses that how prayers can be used to reduce Anxiety.

\section{Literature Review}

Anxiety now a day is a serious threat to life throughout the world. It is more common in women than man but it is found among all segments of society. The exact reason for anxiety is unknown but there are many remedies to combat Anxiety. (Orzechowska, Zajączkowska, Talarowska, \& Gałecki, 2013) carried out a study on 80 patients of anxiety and concluded that healthy people easily manage all events while people who are facing depression and anxiety they are unable to handle situation and event. Which ultimately reach more poor mental health and quality of life. (Poloma \& Pendleton, 1991) Surveyed the usage of prayers for wellbeing. He concluded that the three is a positive relationship between the frequency of prayers and happiness. Prayers can help to manage negative thoughts and increased happiness rates. Strongest the relationship with God increases the satisfaction rate. (Kimball, 2013) found that majority of the people face illness in the form of stress, depression, and anxieties. Prayers easily manage these problems. The results showed that $60 \%$ of the people used prayers to control mental health problems.

(Dunn \& Horgas, 2000) Conducted a cross-sectional survey by collecting data from 50 different communities to find spiritual treatment among elders. The findings indicate that $96 \%$ of people use prayers for coping with mental stress. Black and women pray more to God than white and men. (Wilkins, 2015) indicate that prayers work like medicine for healing mental health. There is a strong connection between faith and healing. Stronger faith in prayers to God increases the healing rate (Golden, 2009). (Byrd, 1988) conducted a study on the role of prayers in healing. He found that those patients who increase prayers frequency their health also improved. (Samano et al., 2004) Prayer is a very common practice used in health care and among people of all ages all over the world. (Tracy et al., 2005) conducted a survey of critical care nurses and found that $73 \%$ used prayers in their practices, $81 \%$ recommended it to patients, and $79 \%$ of people are requested by patients and their family members to pray on behalf of the patient for recovery of health. (Simão et al., 2016) study patients and conclude that prayers are helpful in treatment and healing and it can be included in nursing. 
Although most of the literature suggests that prayers can help to reduce and control Anxiety but (Masters \& Spielmans, 2007) stated that, many people practice prayers and believe that it has positive impacts on their health but there is no scientific evidence available for that. This study concludes that the frequency of prayers and the content of prayers does not affect someone's health.

\section{Research Questions:}

1. What is the percentage of youth facing anxiety problems?

2. What are the major reasons of anxiety among youth?

3. Is there is any change in the intensity of anxiety, among males and females?

4. Are income and age have any effect on anxiety?

\section{Methods}

This study utilized quantitative methodology via a survey method to explore the ratio of anxiety and to highlight the role of prayers to manage anxiety among the youth of Pakistan. In other words, this study is an attempt to investigate the anxiety problem and suggest some remedies to overcome this problem in the youth of Pakistan. For this research, the population is the youth (ranging from 15 to 29 years) living in Lahore, Pakistan.

The systematic random sampling technique was used to collect data from the 400 respondents from the youth of Pakistan Lahore in two phases. In phase one all the respondents were asked if they can recall any event in the past month which makes them annoyed, tense, or irritated. Those who could recall and feel anxiety were selected for further research while the other was dropped. From the chosen respondents we collect further data that was analyzed using SPSS.

\section{Result and Discussion}

For this study total of 400 respondents were selected. In the first phase, they were asked if they face anxiety in the last month. Out of 400, we get responses from 312 respondents. A total of 88 respondents said that they do not face any anxiety while 224 said that they face an anxiety problem in the last month.

\section{Q 1: What is the percentage of youth facing anxiety problems?}

Unlike the previous studies done by (Arif, Naveed, \& Aslam, 2017) which investigate that $44 \%$ of the people in Pakistan are facing anxiety. As mention in the below table (Table 1) $71 \%$ of the youth is facing alarming anxiety.

To make this research more valuable researcher asked to follow up questions from those respondents who were facing anxiety. while the others were excluded from further study.

Table 1: Number of Respondent Facing Anxiety

$\begin{array}{lll}\text { Total respondents } & 312 & \text { Percentage } \\ \text { Facing anxiety problem } & 224 & 71 \% \\ \text { Do not face the anxiety problem } & 88 & 28.2 \%\end{array}$

\section{Q2: What are the major reasons of anxiety among youth?}

From the chosen 224 respondents, researchers asked further questions to investigate the major reasons of anxiety among youth. Researchers asked them about the reason for anxiety, the intensity of anxiety, and how they manage it. Based on their answers researcher categorize their answers as mention in Table 2. The majority of the respondents said that they are facing anxiety due to institutions, such as organizations where they are enrolled. While on the second number they are facing anxiety due to family.

Interestingly Intensity of anxiety is high when the reason for anxiety is family, likewise, they manage anxiety through prayers from God. While the second reason for anxiety among youth is an institution where they work or study. In all cases when the intensity of anxiety is high people start praying to God 
and on a second choice they discuss their problems with their friends. This is also alarming that family is the last choice in managing anxiety.

Table 2: Reasons of Anxiety

\begin{tabular}{|c|c|c|c|}
\hline \multicolumn{2}{|c|}{ What was the cause of your anxiety? } & Frequency & Percent \\
\hline \multicolumn{2}{|l|}{ Family } & 67 & 29.9 \\
\hline \multicolumn{2}{|l|}{ Institution } & 77 & 34 \\
\hline \multicolumn{2}{|l|}{ Friends } & 44 & 19 \\
\hline \multicolumn{4}{|c|}{ What was the intensity of your anxiety? } \\
\hline \multirow{4}{*}{ Family } & Low & 2 & 7.1 \\
\hline & Normal & 6 & 21.4 \\
\hline & High & 20 & 71.4 \\
\hline & Low & 7 & 18.9 \\
\hline \multirow[t]{3}{*}{ Institution } & Normal & 13 & 35.1 \\
\hline & High & 16 & 43.2 \\
\hline & Low & 3 & 13.0 \\
\hline \multirow[t]{2}{*}{ Friends } & Normal & 11 & 47.8 \\
\hline & High & 8 & 34.8 \\
\hline \multicolumn{4}{|c|}{ How you manage your anxiety? } \\
\hline \multirow{3}{*}{ Family } & Through discussion with friends & 6 & 21.4 \\
\hline & By praying to God & 22 & 78.6 \\
\hline & Takes help from Family & 4 & 10.8 \\
\hline \multirow[t]{3}{*}{ Institution } & Through discussion with friends & 10 & 27.0 \\
\hline & By praying to God & 23 & 62.2 \\
\hline & Takes help from Family & 2 & 8.7 \\
\hline \multirow[t]{2}{*}{ Friends } & Through discussion with friends & 9 & 39.1 \\
\hline & By praying to God & 12 & 52.2 \\
\hline
\end{tabular}

\section{Q3: Is there is any change in the level of intensity, among males and females?}

As highlighted in Table 3, the intensity of anxiety is higher in girls than in boys. As compared to boy's frequency of prayers is higher in girls. This also shows that greater the intensity of anxiety leads to a higher frequency of prayers. Likewise, as the intensity of anxiety is higher in girls, the duration of their anxiety becomes higher than boys. Or in other words, their anxiety remains for a longer period as compared to boys.

Interestingly as compare to girls the majority of boys manage anxiety through discussion with their friends while the majority of girls manage anxiety through prayers from God and they do not discuss it with friends. While both for boys and girl's family is the last or even not an option to discuss their anxiety and find a solution. 
Table 3: Gender and Anxiety

\begin{tabular}{llll}
\hline 1: What was the intensity of your anxiety? & Frequency & Percent \\
\multirow{2}{*}{ Male } & Low & 12 & 15.8 \\
& Normal & 27 & 35.5 \\
& High & 36 & 47.4 \\
\multirow{2}{*}{ Female } & Low & 1 & 4.5 \\
& Normal & 6 & 27.3 \\
& High & 14 & 63.6
\end{tabular}

2: What is the frequency of your prayer?

\begin{tabular}{|c|c|c|c|}
\hline \multirow{3}{*}{ Male } & Several times a day & 43 & 56.6 \\
\hline & Once a day & 25 & 32.9 \\
\hline & Once a week & 7 & 9.2 \\
\hline \multirow{3}{*}{ Female } & Several times a day & 15 & 68.2 \\
\hline & Once a day & 7 & 31.8 \\
\hline & Once a week & & \\
\hline \multicolumn{4}{|c|}{ 3: How long you face anxiety? } \\
\hline \multirow{3}{*}{ Male } & Less than one hour & 23 & 30.3 \\
\hline & 1 to 24 Hours & 23 & 30.3 \\
\hline & More than one Day & 30 & 39.5 \\
\hline \multirow{2}{*}{ Female } & Less than one hour & 2 & 9.1 \\
\hline & 1 to 24 Hours & 8 & 36.4 \\
\hline \multicolumn{4}{|c|}{ 4: How you manage your anxiety? } \\
\hline \multirow{3}{*}{ Male } & Takes help from Family & 6 & 7.9 \\
\hline & Through discussion with friends & 22 & 28.9 \\
\hline & By praying to God & 48 & 63.2 \\
\hline \multirow{3}{*}{ Female } & Takes help from Family & 2 & 9.1 \\
\hline & Through discussion with friends & 4 & 18.2 \\
\hline & By praying to God & 16 & 72.7 \\
\hline
\end{tabular}

\section{Q4: Are income and age have any effect on anxiety?}

Table 4 shows that the intensity of anxiety increase with an increase in age. Likewise, as the intensity of anxiety increase, the frequency of prays also increase to overcome the anxiety. The majority of the respondent said that they manage their anxiety by praying to God and on the second option they talk to their friends to overcome anxiety. Only a few of the respondents said that they manage anxiety with the help of family.

Table 4: Age and Anxiety

\begin{tabular}{llll}
\hline \multicolumn{2}{l}{ 1: What was the intensity of your anxiety? } & Frequency & Percent \\
\multirow{2}{*}{18 to 21 Years } & Low & 12 & 16.7 \\
& Normal & 24 & 33.3 \\
\hline
\end{tabular}




\begin{tabular}{|c|c|c|c|}
\hline & High & 34 & 47.2 \\
\hline \multirow{3}{*}{22 to 25 Years } & Low & 1 & 4.3 \\
\hline & Normal & 7 & 30.4 \\
\hline & High & 15 & 65.2 \\
\hline
\end{tabular}

2: What is the frequency of your prayers?

\begin{tabular}{|c|c|c|c|}
\hline \multirow{3}{*}{18 to 21 Years } & Several times a day & 42 & 58.3 \\
\hline & Once a day & 23 & 31.9 \\
\hline & Once a week & 6 & 8.3 \\
\hline \multirow{3}{*}{22 to 25 Years } & Several times a day & 14 & 60.9 \\
\hline & Once a day & 8 & \\
\hline & Once a week & 1 & 4.3 \\
\hline & Several times a day & 2 & 66.7 \\
\hline 22 to 29 Years & Once a day & 1 & 33.3 \\
\hline
\end{tabular}

\section{3: How you manage your anxiety?}

$\begin{array}{lll}\text { Takes help from Family } & 5 & 6.9\end{array}$

18 to 21 Years $\quad$ Through discussion with friends $\quad 20 \quad 27.8$

By praying to God $47 \quad 65.3$

Takes help from Family $\quad 3 \quad 13.0$

22 to 25 Years $\quad$ Through discussion with friends $\quad 5 \quad 21.7$

By praying to God $\quad 15 \quad 65.2$

Through discussion with friends $\quad 1 \quad 33.3$

22 to 29 Years $\quad$ By praying to God $\quad 2 \quad 66.7$

As highlighted in table 5, the economic condition has a very interesting relationship with anxiety. Those who earn more money face a high level of anxiety than those with low monthly income. The majority of people with more monthly income face more anxiety and they pray several times a day.

Table 5: Income and Anxiety

\begin{tabular}{|c|c|c|c|}
\hline \multicolumn{2}{|c|}{ What was the intensity of your anxiety? } & Frequency & Percent \\
\hline \multirow{3}{*}{$\begin{array}{l}\text { Less than } 50 \\
\text { thousand per Month }\end{array}$} & Low & 5 & 16.7 \\
\hline & Normal & 13 & 43.3 \\
\hline & High & 12 & 40.0 \\
\hline \multirow{3}{*}{$\begin{array}{l}50 \text { thousand to } 1 \\
\text { Lakh per Month }\end{array}$} & Low & 5 & 12.5 \\
\hline & Normal & 12 & 30.0 \\
\hline & High & 21 & 52.5 \\
\hline \multirow{3}{*}{$\begin{array}{l}\text { More than } 1 \text { Lakh } \\
\text { per Month }\end{array}$} & Low & 1 & 4.3 \\
\hline & Normal & 7 & 30.4 \\
\hline & High & 15 & 65.2 \\
\hline \multicolumn{4}{|c|}{ What is the frequency of your prayer? } \\
\hline than $\quad 50$ & Several times a day & 14 & 46.7 \\
\hline
\end{tabular}




\begin{tabular}{|c|c|c|c|}
\hline \multirow[t]{3}{*}{ thousand per Month } & Once a day & 11 & 36.7 \\
\hline & Once a week & 4 & 13.3 \\
\hline & Several times a day & 24 & 60.0 \\
\hline \multirow{3}{*}{$\begin{array}{l}50 \text { thousand to } 1 \\
\text { Lakh per Month }\end{array}$} & Once a day & 13 & 32.5 \\
\hline & Once a week & 3 & 7.5 \\
\hline & Several times a day & 16 & 69.6 \\
\hline $\begin{array}{l}\text { More than } 1 \text { Lakh } \\
\text { per Month }\end{array}$ & Once a day & 7 & 30.4 \\
\hline
\end{tabular}

\section{Discussion}

Anxiety is one of the top diseases in the world which leads to many other diseases among all ages of people. This paper addresses the anxiety problem faced by the youth of Pakistan Lahore. The researchers collected data from the target population in two phases. In phase one data is collected from 400 respondents through a systematic random sampling technique from university students. Among 400 respondents 224 respondents or $71 \%$ said that they face anxiety in the last month. While 88 respondents or $28.2 \%$ said that they do not face any anxiety problem. For phase two researchers drop all those respondents who did not face anxiety while further questioned were asked only from those who face anxiety in the last month. The researchers concluded that the intensity of anxiety is higher in girls than in boys. Therefor girls most frequently pray to God to manage anxiety. Likewise, anxiety in girls remains for a longer time than boys and a large number of girls take help of God while boys discuss it with friends. Researchers also found that anxiety problems increase with age. As the age increase, the intensity and duration of anxiety also increase. And when the intensity of anxiety increases the frequency of prayers also increases. Economic conditions are also linked with anxiety as those who are wealthy are facing more anxiety than those with low economic status. Likewise, those with high socioeconomic status and more wealth their frequency of prayers to God also increase.

In youth, the major reason of facing anxiety is family and those who face anxiety problems from family there intensity of anxiety is higher and they pray to God more frequently. While on the second number majority of youth facing anxiety due to institutions where they study, which can also lead to illiteracy due to UN professionalism in educational institutions. Interestingly the majority of the youth manage their anxiety through prayers from God, on the second choice they discuss it with their friends while only a few respondents discuss their anxiety problem with family members. Research also found that when the intensity of anxiety is high the duration of anxiety is also high and when the intensity of anxiety is low then the duration of the anxiety is also low. This research conclude that spiritual communication can help the management of anxiety among youth.

\section{Recommendations}

As mention in the holy book Quran (28-13) your heart will find peace only in the remembrance of Allah. The findings of this study suggest that around 71 percent of the people of Pakistan are facing the anxiety problem nowadays. Not only men, but a large number of girls are also facing this disease. This paper also concludes that wealth is not the reason for happiness, as those who are earning more money, their life is tenser than those who are hardly earning their living expenses. The findings of this paper recommend that, as in this materialistic life, our youth is going away from the religion therefore anxiety is becoming more common among them. As most of the respondents revealed that they manage their anxiety through spiritual communication, this paper recommends that anxiety can be handled, reduce, and even control through the prayers among the youth of Pakistan.

\section{References}

Arif, A., Naveed, S., \& Aslam, R. (2017). Factors causing stress among Pakistani working women. 
Pakistan Administrative Review, 1(3), 159-174.

Byrd, R. C. (1988). Positive therapeutic effects of intercessory prayer in a coronary care unit population.

Dunn, K. S., \& Horgas, A. L. (2000). The prevalence of prayer as a spiritual self-care modality in elders. Journal of Holistic Nursing, 18(4), 337-351.

Golden, R. L. (2009). William Osler, urolithiasis, and God's own medicine. Urology, 74(3), 517-521.

Harris, S. T. (2008). The impact of spirituality on health conditions of persons with diabetes in Eastern North Carolina: East Carolina University.

Jim, H. S., Pustejovsky, J. E., Park, C. L., Danhauer, S. C., Sherman, A. C., Fitchett, G., . . Snyder, M. A. (2015). Religion, spirituality, and physical health in cancer patients: A meta-analysis. Cancer, 121(21), 3760-3768.

Kay, J., \& Tasman, A. (2006). Essentials of psychiatry: Wiley Online Library.

Kimball, B. M. (2013). A Practical Meta-Analysis of Prayer Efficacy in Coping with Mental Health.

Levin, J. S. (1996). How prayer heals: a theoretical model. Alternative Therapies in Health and Medicine, 2(1), 66-73.

Levin, J. S., \& Taylor, R. J. (1997). Age differences in patterns and correlates of the frequency of prayer. The Gerontologist, 37(1), 75-88.

Malik, N. A., \& Björkqvist, K. (2018). Occupational Stress and Mental and Musculoskeletal Health Among University Teachers. EURASIAN JOURNAL OF MEDICAL INVESTIGATION, 2(3), 139-147.

Masters, K. S., \& Spielmans, G. I. (2007). Prayer and health: Review, meta-analysis, and research agenda. Journal of behavioral medicine, 30(4), 329-338.

Moreira-Almeida, A., Lotufo Neto, F., \& Koenig, H. G. (2006). Religiousness and mental health: a review. Brazilian Journal of Psychiatry, 28(3), 242-250.

Orzechowska, A., Zajączkowska, M., Talarowska, M., \& Gałecki, P. (2013). Depression and ways of coping with stress: A preliminary study. Medical science monitor: international medical journal of experimental and clinical research, 19, 1050.

Panzini, R. G., \& Bandeira, D. R. (2007). Coping (enfrentamento) religioso/espiritual. Revista de psiquiatria clínica. São Paulo. Vol. 34, supl1 (2007), p. 126-135.

Poloma, M. M., \& Pendleton, B. F. (1991). The Effects of Prayer and Prayer Experiences on Measures of General Weil-Being. Journal of Psychology and Theology, 19(1), 71-83.

Samano, E. S. T., Goldenstein, P. T., Ribeiro, L. d. M., Lewin, F., Valesin Filho, E. S., Soares, H. P., \& Giglio, A. d. (2004). Praying correlates with higher quality of life: results from a survey on complementary/alternative medicine use among a group of Brazilian cancer patients. Sao Paulo Medical Journal, 122(2), 60-63.

Simão, T., Caldeira, S., \& de Carvalho, E. (2016). The effect of prayer on patients' health: systematic literature review. Religions, 7(1), 11.

Smolensky, M. H. (1998). Knowledge and attitudes of American physicians and public about medical chronobiology and chronotherapeutics. Findings of two 1996 Gallup surveys. Chronobiology international, 15(4), 377-394.

Stephenson, N., Weinrich, S. P., \& Tavakolil, A. S. (2000). The effects of foot reflexology on anxiety and pain in patients with breast and lung cancer. Paper presented at the Oncology Nursing Forum-Oncology Nursing Society.

Tracy, M. F., Lindquist, R., Savik, K., Watanuki, S., Sendelbach, S., Kreitzer, M. J., \& Berman, B. (2005). Use of complementary and alternative therapies: a national survey of critical care nurses. American Journal of Critical Care, 14(5), 404-415.

Wilkins, L. (2015). The Research on Prayer and Healing: Past, Present and Future Challenges. 